\title{
Evaluation of the Gravataí River sediment quality (Rio Grande do Sul- Brazil) using Daphnia magna (Straus, 1820) as the test-organism for toxicity assays
}

\author{
Avaliação da qualidade dos sedimentos do rio Gravataí \\ (Rio Grande do Sul - Brasil) a partir de testes de toxicidade utilizando \\ Daphnia magna (Straus, 1820) como organismo-teste
}

Fabiane Lucheta, Ilda Rosa Feiden, Silvana Pereira Gonçalves, Juliana Schons Gularte and Nara Regina Terra

Fundação Estadual de Proteção Ambiental Henrique Luis Roessler - FEPAM, Av. Dr. Salvador França, 1707, Bairro Jardim Botânico, CEP 90690-000, Porto Alegre, RS, Brazil

e-mail: fabianelucheta@hotmail.com; ilda.feiden@gmail.com; silvana.goncalves@acad.pucrs.br; julianaschons@hotmail.com; nara.terra@ufrgs.br

\begin{abstract}
Aim: Persistent pollutants released to riverbeds return to the trophic system, damaging living organisms thereof. Ecotoxicological assays express the effect of environmental interactions with organisms found there. Assays were performed with microcrustacean Daphnia magna (Straus, 1820) in sediment samples, from the headwaters to the mouth, in order to evaluate the Gravataí River quality; Methods: Bottom sediment was used to evaluate the responses of cladocerans to environmental changes in 15 samples collected between Jan./06 and May/09. The microcrustaceans were submitted to stress for 21 days from birth (2-26 hours old). Duncan Test, percentage survival, reproduction and Spearman Correlation were used to evaluate the quality of the sites; Results: Duncan Test showed a significant difference $(\mathrm{p} \leq 0.05)$ in reproduction in 14 of the 15 samplings, and chronic action was more constant $(88 \%)$ than the acute one $(23 \%)$. Changes in survival and reproduction related to season or rainfall regime were only observed on a few occasions. The two sites located close to the mouth presented a Spearman Correlation $(\mathrm{p} \leq 0.01)$ for survival and reproduction. There were changes in some samplings in the headwaters as a result of sewage discharges in the area; Conclusions: Fluctuating responses were observed in this river due to anthropic contaminants, slow flux and current reflux.
\end{abstract}

Keywords: Cladoceran, microcrustacean, ecotoxicology, pollution, chronic assays.

Resumo: Objetivo: Poluentes persistentes lançados no leito dos rios retornam ao sistema trófico danificando os organismos que o integram. Os ensaios ecotoxicológicos expressam o efeito das interaçóes ambientais com os organismos ali presentes. Visando avaliar a qualidade do rio Gravataí foram realizados ensaios com o microcrustáceo Daphnia magna (Straus, 1820), em amostras do sedimento, da nascente até a foz; Métodos: Sedimento de fundo foi utilizado na avaliação das respostas dos cladóceros às alteraçôes ambientais de 15 amostras coletadas entre Jan./06 e Maio/09. Os microcrustáceos foram colocados em situação de estresse durante 21 dias desde o início de suas vidas (2-26 horas). O Teste de Duncan, percentual de sobrevivência, reprodução e Correlação de Spearman foram utilizados para avaliar a qualidade dos locais; Resultados: O Teste de Duncan mostrou diferença significativa $(\mathrm{p} \leq 0,05)$ na reprodução em 14 das 15 amostragens, sendo a ação crônica mais constante ( $88 \%$ ) que a aguda $(23 \%)$. Somente em algumas ocasióes foram observadas alterações na sobrevivência e na reprodução relacionadas à estação climática ou regime de chuvas. Os dois locais situados próximos a foz apresentaram Correlaçáo de Spermann $(\mathrm{p} \leq 0,01)$ para sobrevivência e reprodução. Aqueles situados na nascente mostraram alteraçôes em algumas amostragens em decorrência dos lançamentos de esgotos na área; Conclusóes: Flutuações de respostas foram observadas neste rio devido aos contaminantes de origem antrópica, fluxo lento e refluxo de correntes.

Palavras-chave: Cladocera, microcrustáceo, ecotoxicologia, poluição, ensaios crônicos. 


\section{Introduction}

Chronic assays are important to obtain information about the impact of effluent discharges or other forms of contamination. Long duration assays should be preferred since they allow the manifestation of environmental stressors that are not detectable by traditional physical and chemical methods or short duration bioassays. This type of assay helps obtain information on the quality of bottom sediment, especially when the organisms used can ingest products retained there. In recent years, many methods have been developed to assess contaminants in sediments, since they have been potential sources of water contamination.

Anthropic actions such as domestic and industrial effluent discharges and river bed dredging activities have modified the ecosystems, triggering changes in environmental quality and in the capacity of self-depuration and recovery of the balance of water bodies. Rivers like the Gravataí with their source in wetlands are more sensitive to these changes and require periodical evaluations. Runoff transporting sediment with a high concentration of $\mathrm{P}$ has been identified as one of the main routes of this element into surface water, and as threatening environmental quality due to its capacity to stimulate eutrophication in freshwater (Ballantine et al., 2009), a phenomenon that often occurs in this river.

Highly polluted areas are present in the watercourse all the way downstream from the headwaters. They alternate with others that are less affected, leading to variable responses, as seen in previous studies (Terra et al., 2004; 2009; Salomoni et al., 2007) and confirmed in this one.

Santo Antônio da Patrulha, Taquara, Glorinha, Gravataí, Alvorada, Viamão, Cachoeirinha, Canoas and Porto Alegre, the municipalities bathed by Gravataí River, are responsible for its degradation (FEPAM, 1996). The area of Banhado Grande, its main source and flow regulator, was much reduced according to studies by DNOS/GTZ (1985).

Sediment samples were used as a substrate for Daphnia magna Straus, 1820 because this species is appropriate for this kind of assay (Nebeker et al., 1984). Daphnia is the dominant zooplankton in many freshwater systems and could substantially influence the overall biogeochemical cycling of the trace metals as a result of their grazing activities (Yu and Wang, 2002). Moreover, this genus is a non-selective filter using the material aggregated to the superficial layer of sediment functioning as an epibenthic species (Burton, 1992). Suedel et al.
(1996) observed that daphnids graze on the surface when they are $\geq 48$ hours old. According to Evens et al. (2009) Ni, a metal discharged in metallurgical effluents and found in the Gravataí River sediment, significantly reduces the reproduction of D. magna in 21-day tests.

The present study aimed at performing the ecotoxicological characterization and providing information about the effect on cladocerans of contaminants discharged by different effluents or carried into the river by soil.

\section{Material and Methods}

Sediments collected (15) between Jan./06 and May/09 at five sites on Gravataí River, were used to characterize the area for the survival and reproduction of $D$. magna.

The sampling points were identified using the first two letters of the river name $(\mathrm{Gr})$ and the distance from the mouth in kilometers $(72,34,28$, 08 and $06 \mathrm{~km}$ ) (Figure 1). Information provided by the surface waters Monitoring Network of the Fundação Estadual de Proteção Ambiental do Estado (FEPAM) describes each site and the main sources of pollution.

\subsection{Sampling stations}

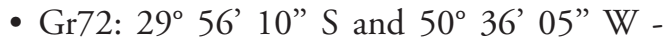
(Banhado Chico Lomã) - agriculture, sanitary and industrial sewage;

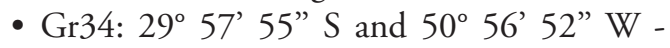
(Passo dos Negros) - irrigated rice and livestock;

- Gr28: $29^{\circ} 57^{\prime} 22^{\prime \prime S}$ and 51 00'59” Wsanitary and industrial sewage;

- Gr08: $29^{\circ} 57^{\prime} 16^{\prime \prime} \mathrm{S}$ and 51 $07^{\circ} 36^{\prime \prime} \mathrm{W}$ navigation, storm drainage, sanitary and industrial sewage and garbage; and

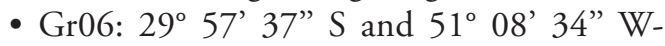
(Areia Brook) - navigation, storm drainage, sanitary and industrial sewage.

Gr72 and Gr34 are classified as Class 1 sites, while Gr28, Gr08 and Gr06 are classified as Class 2, according to Brazilian legislation (CONAMA, 2005). Class 1 includes waters for human consumption after simplified treatment, protection of aquatic communities, primary contact recreation, irrigation of vegetable and fruit to be eaten raw, besides the protection of aquatic communities in Indigenous Territories. Class 2 includes water for human consumption after conventional treatment, protection of aquatic communities, primary contact recreation, irrigation of vegetables, orchards, parks, 


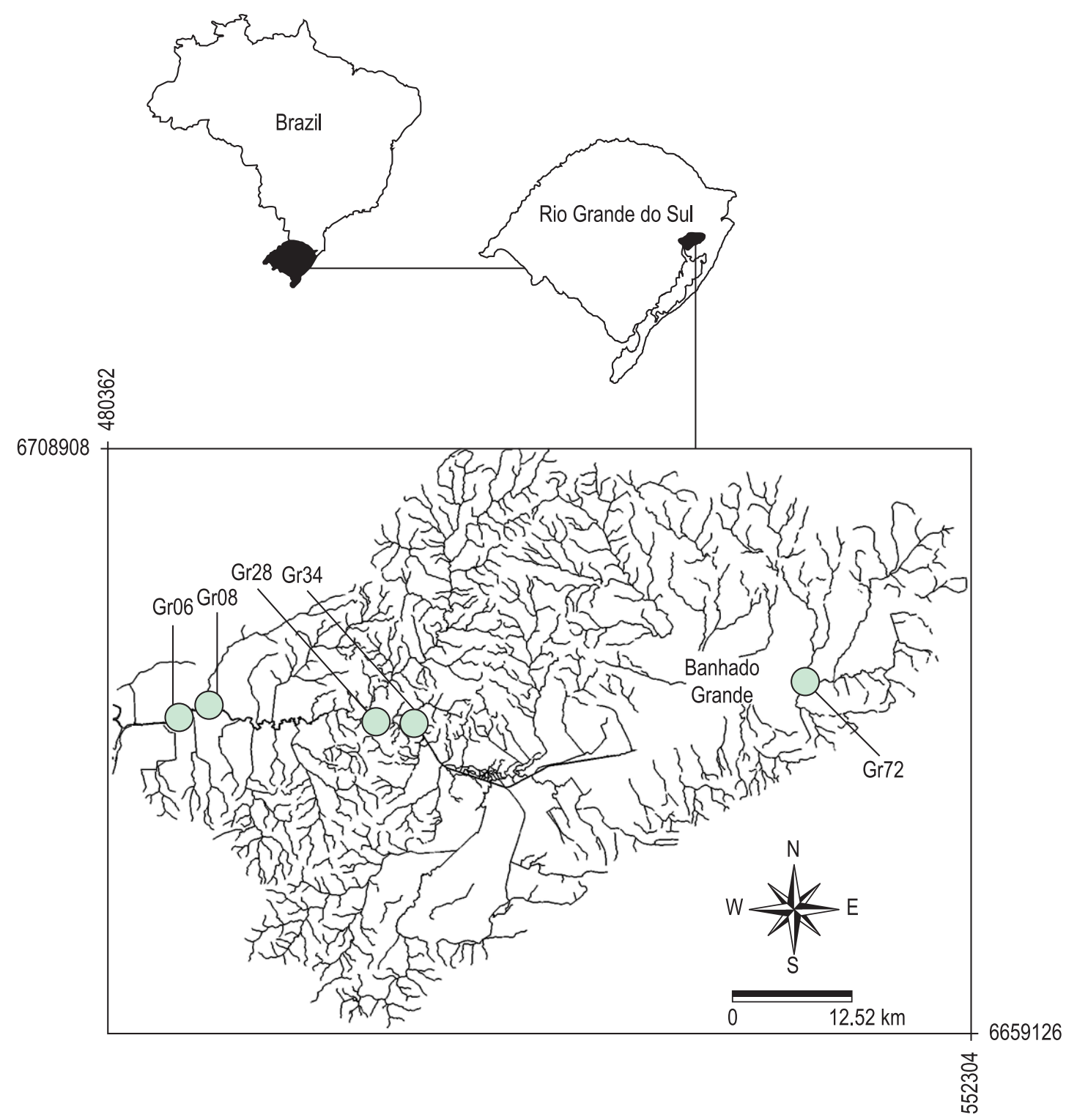

Figure 1. Sites Gr72, Gr34, Gr28, Gr08 and Gr06. Gravataí River Basin, Rio Grande do Sul State, Brazil. (Adapted map of Salomoni et al. (2007).

gardens, sports fields and leisure areas, with which the public may come into direct contact, besides aquaculture and fishing.

A Petersen grab sampler was used to sample the sediment. The sediment was placed in glass flasks and transported to the laboratory on ice, protected from light. There the samples were kept in the dark at $4{ }^{\circ} \mathrm{C}$ for up to a month.

Lots of 25 adults cultivated in $1000 \mathrm{~mL}$ of M4 medium ( $\mathrm{pH} \mathrm{7.8,} \mathrm{total} \mathrm{hardness} 230 \mathrm{mg}$ $\mathrm{CaCO}_{3} / \mathrm{L}$ ) (Elendt and Bias, 1990) at $20^{\circ} \mathrm{C}+/-2{ }^{\circ} \mathrm{C}$ and photoperiod of 16 hours ligh $/ 8$ hours dark supplied the mothers. Daphnia magna born from lots presenting LC50-24 hours = $1.02^{+} /-0.13 \mathrm{mg}$ to potassium dichromate $\left(\mathrm{K}_{2} \mathrm{Cr}_{2} \mathrm{O}_{7}\right)$ were used. The Trimmed Spearman-Karber method (Hamilton et al., 1977) was used to calculate LC50. All experiments were conducted in incubators at $20 \pm 2{ }^{\circ} \mathrm{C}$ under cool white fluorescent light with a 16 hours light/ 8 hours dark photoperiod (Gersich and Mayes, 1986; Pieters and Liess, 2006).

Ten test-organisms (2 to 26 hours old), distributed in beakers with a nominal value of $50 \mathrm{~mL}$, containing sediment and M4 medium (1:4; $\mathrm{v}: \mathrm{v})$ were used per sample.

Mortality (total lack of movement) and births were observed for 21 days, on Mondays, Wednesdays and Fridays. After counting, dead matrix and neonates were eliminated, the liquid medium was replaced by a recent medium and 
the sediment was kept until the end. Whenever the mortality was greater than $20 \%$, the site was identified as an inducer of acute toxicity, and when the mean number of neonates per brood was less than 20, classified as inducing chronic toxicity. The assays in which survival was above $80 \%$ (ABNT, 2005) and the mean number of neonates per brood was 20 individuals were validated (Cowgill et al., 1985).

Scenedesmus subspicatus $\left(0.7 \mathrm{~mL} ; 10^{7}\right.$ cells. $\left.\mathrm{cm}^{-3}\right)$ and fish chow complemented with biological yeast $(0.1 \mathrm{~mL})$ were used as food. The food prepared with fish chow and yeast followed the methodology recommended in ABNT-NBR 12713 (2004). The algae were cultivated according to Chu (1942). This amount of food is enough to ensure the nutrition and health of the test-organisms.

Mean births per brood, percentage survival, Duncan Test (SPSS 9.0 for Windows/2002) and Spearman Correlation (SPSS 9.0) were used to evaluate the data. Duncan Test $(\mathrm{p} \leq 0.05)$ compared the variation of the responses at each site over time and between the sites within each month. The Spearman Correlation compared information on reproduction, survival and rainfall. The means of monthly rainfalls and historical series (1970/2000) used in the study were provided by the Fundação Estadual de Pesquisa Agropecuária (FEPAGRO).

\section{Results}

Alterations in the Gravataí River quality were evaluated in this study based on the results obtained. Acute actions occurred in $23 \%$ of the exposures, distributed as follows: Jan./06 (Gr28),
Mar./06 (Gr06, Gr28, Gr34), July/06 (Gr34), May/07 (Gr06, Gr08, Gr72), Nov./07 (Gr34), Jan./08 (Gr08), July/08 (Gr34), Nov./08 (Gr06), Mar./09 (Gr06, Gr08), May/09 (Gr06, Gr08, Gr28) (Figure 2).

Chronic toxicity, however, was detected more frequently (88\%). Diminished reproduction of the mothers occurred constantly, save for the samples of Mar./06 (Gr06, Gr08), May/07 (Gr72), Sept./07 (Gr34), Jan./08 (Gr06, Gr72), July/08 (Gr28) Sept./08 (Gr06), Mar./09 (Gr28) (Figure 3).

Using Duncan Test only Nov./08 did not show a significant difference in reproduction when the points were compared. Although two groups were established that month, no significance between the differences was found (Table 1). The same table shows a similarity between the subsequent sites: Gr06, Gr08 and Gr28 (Mar./07, Sept./07, July/08); Gr06 and Gr08 (May/09); Gr28, Gr34 and Gr72 (May/09). When a difference was established between the neonate production of the control and the samples, it was clear that the numbers were more different from the control group in Jan./06 and more similar in Jan./08. It should be pointed out that in Jan./08, Sept./08 and Mar./09, the numbers were even greater than the control group (Figure 4).

When the results of the reproduction of each group were compared throughout the sampling period, nine groups of differentiated combinations were obtained for Gr34, six for Gr72 and seven for the others, according to Duncan Test ( $\mathrm{p} \leq 0.01$ ) (Figure 5).

Gr06, Gr08 and Gr34 showed a Spearman Correlation $(\mathrm{p} \leq 0.05)$ between rainfall and survival. Gr06 and Gr08 presented a Spearman Correlation

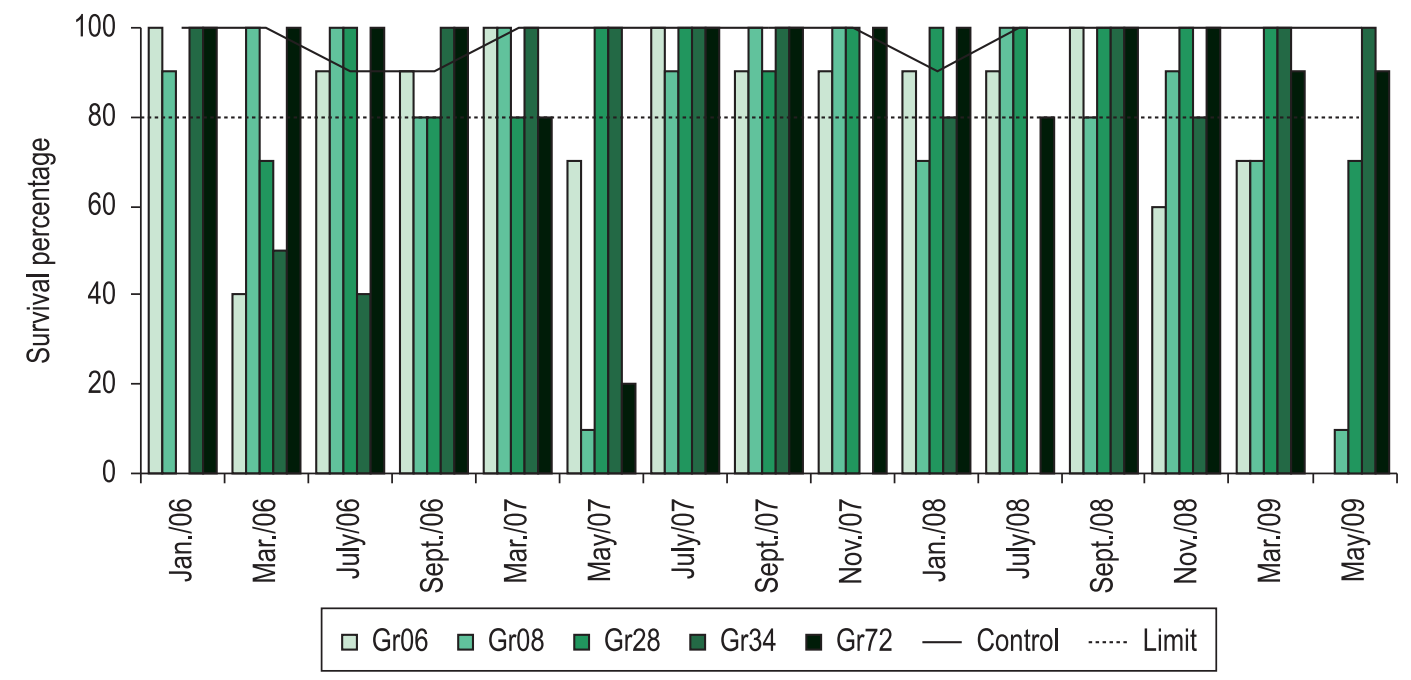

Figure 2. Survival of Daphnia magna exposed to Gravataí River sediment samples, control group and expected survival from January/2006 to May/2009. 


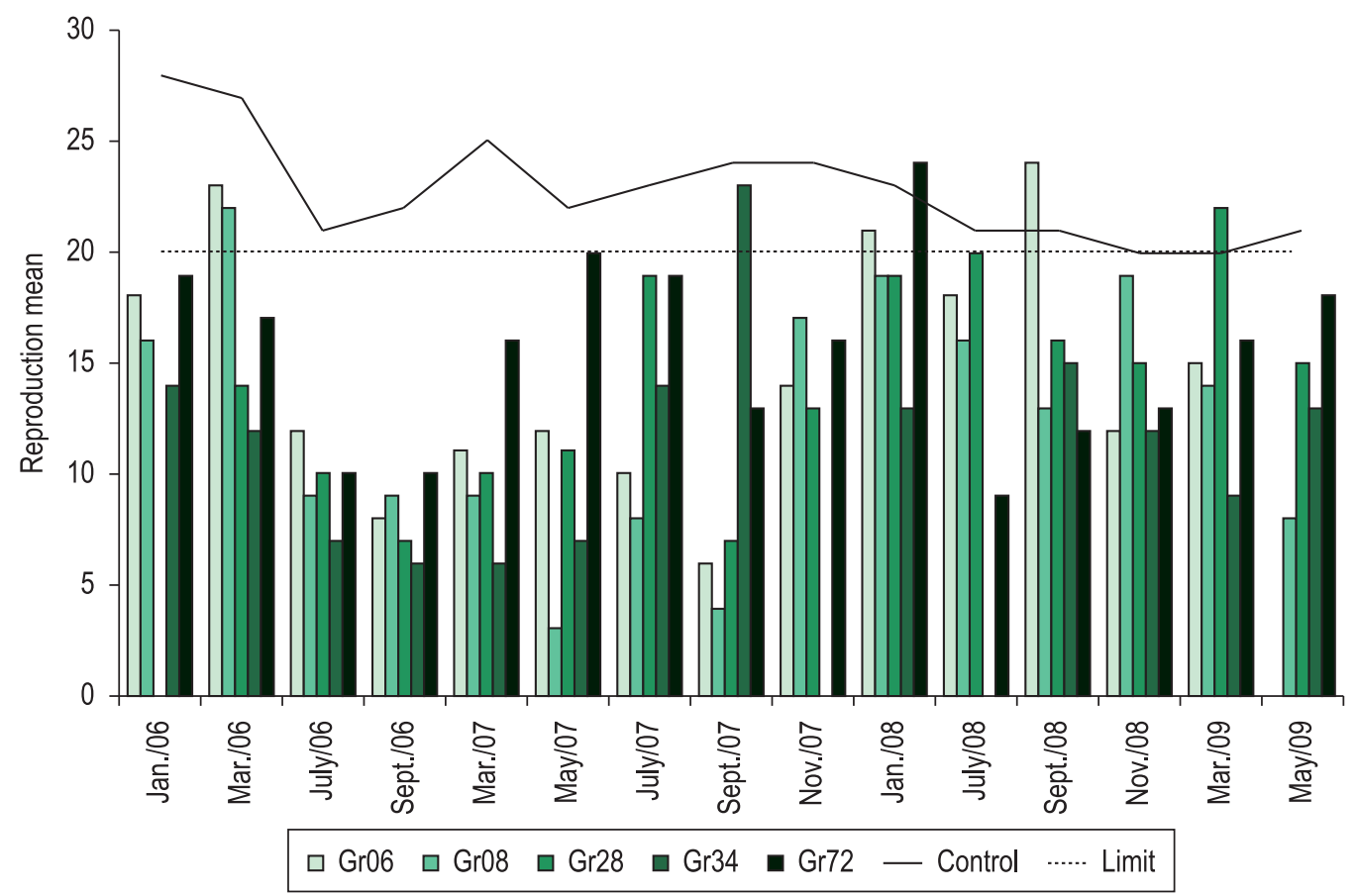

Figure 3. Mean reproduction of Daphnia magna exposed to Gravataí River sediment samples, control group and expected mean, from January/2006 to May/2009.

Table 1. Comparison of means between sites per month.

\begin{tabular}{|c|c|c|c|c|c|c|c|c|c|}
\hline \multicolumn{2}{|c|}{ Jan./06 } & \multicolumn{2}{|c|}{ Mar./06 } & \multicolumn{2}{|c|}{ July/06 } & \multicolumn{2}{|c|}{ Sept./06 } & \multicolumn{2}{|c|}{ Mar./07 } \\
\hline Site & Mean & Site & Mean & Site & Mean & Site & Mean & Site & Mean \\
\hline Gr28 & $0^{\mathrm{a}}$ & Gr34 & $29.7^{a}$ & Gr34 & $14.3^{\mathrm{a}}$ & Gr34 & $32^{\mathrm{a}}$ & Gr34 & $28.8^{\mathrm{a}}$ \\
\hline Gr34 & $68^{b}$ & Gr06 & $49.2^{\mathrm{a}, \mathrm{b}}$ & Gr08 & $46.3^{b}$ & Gr28 & $32.4^{a}$ & Gr08 & $45.5^{\mathrm{a}, \mathrm{b}}$ \\
\hline Gr08 & $74.5^{\mathrm{b}, \mathrm{c}}$ & Gr28 & $52.5^{\mathrm{a}, \mathrm{b}}$ & Gr72 & $48.3^{b}$ & Gr08 & $38^{a, b}$ & Gr28 & $51.6^{b}$ \\
\hline Gr06 & $91^{\mathrm{c}, \mathrm{d}}$ & Gr72 & $83.2^{b, c}$ & Gr28 & $49^{b}$ & Gr06 & $44.7^{b, c}$ & Gr06 & $55.2^{b}$ \\
\hline Gr72 & $93.7^{\mathrm{d}}$ & Gr08 & $108.7^{c}$ & Gr06 & $54.6^{\mathrm{b}}$ & Gr72 & $50.2^{c}$ & Gr72 & $63.2^{b}$ \\
\hline \multicolumn{2}{|c|}{ May/07 } & \multicolumn{2}{|c|}{ July/07 } & \multicolumn{2}{|c|}{ Sept./07 } & \multicolumn{2}{|c|}{ Nov./07 } & \multicolumn{2}{|c|}{ Jan./08 } \\
\hline Site & Mean & Site & Mean & Site & Mean & Site & Mean & Site & Mean \\
\hline Gr08 & $1.5^{\mathrm{a}}$ & Gr08 & $35.5^{\mathrm{a}}$ & Gr08 & $19.3^{\mathrm{a}}$ & Gr34 & $0^{\mathrm{a}}$ & Gr34 & $59.3^{\mathrm{a}}$ \\
\hline Gr34 & $36.1^{b}$ & Gr06 & $49.7^{\mathrm{a}}$ & Gr06 & $28^{a}$ & Gr28 & $64.3^{b}$ & Gr08 & $67.3^{\mathrm{a}, \mathrm{b}}$ \\
\hline Gr06 & $40.3^{b, c}$ & Gr34 & $70.5^{b}$ & Gr28 & $33^{a}$ & Gr06 & $66.5^{b}$ & Gr28 & $95.7^{b, c}$ \\
\hline Gr28 & $56.6^{c}$ & Gr72 & $94.3^{c}$ & Gr72 & $66.2^{\mathrm{b}}$ & Gr08 & $76.1^{\mathrm{b}}$ & Gr06 & $103.3^{c}$ \\
\hline Gr72 & $58.4^{c}$ & Gr28 & $97.1^{\mathrm{c}}$ & Gr34 & $114.1^{c}$ & Gr72 & $82.7^{b}$ & Gr72 & $120.3^{c}$ \\
\hline \multicolumn{2}{|c|}{ July/08 } & \multicolumn{2}{|c|}{ Sept./08 } & \multicolumn{2}{|c|}{ Nov./08 } & \multicolumn{2}{|c|}{ Mar./09 } & \multicolumn{2}{|c|}{ May/09 } \\
\hline Site & Mean & Site & Mean & Site & Mean & Site & Mean & Site & Mean \\
\hline Gr34 & $0^{\mathrm{a}}$ & Gr08 & $51.9^{a}$ & Gr06 & $37.3^{\mathrm{a}}$ & Gr34 & $45.8^{\mathrm{a}}$ & Gr06 & $0^{\mathrm{a}}$ \\
\hline Gr72 & $38.1^{b}$ & Gr72 & $58.4^{a, b}$ & Gr34 & $52.4^{\mathrm{a}, \mathrm{b}}$ & Gr08 & $56.4^{\mathrm{a}}$ & Gr08 & $5.8^{\mathrm{a}}$ \\
\hline Gr08 & $82.2^{\mathrm{c}}$ & Gr34 & $73.9^{b}$ & Gr72 & $64^{a, b}$ & Gr06 & $61.4^{\mathrm{a}}$ & Gr28 & $62.3^{b}$ \\
\hline Gr06 & $82.9^{c}$ & Gr28 & $80.9^{b, c}$ & Gr08 & $88.6^{\mathrm{a}, \mathrm{b}}$ & Gr72 & $71.5^{\mathrm{a}}$ & Gr34 & $63.8^{b}$ \\
\hline Gr28 & $99^{\circ}$ & Gr06 & $118.7^{d}$ & Gr28 & $158.5^{b}$ & Gr28 & $111.9^{b}$ & Gr72 & $82.8^{b}$ \\
\hline
\end{tabular}

Means followed by the same letter did not differ significantly by LSD test $(\mathrm{p} \leq 0.05)$. 


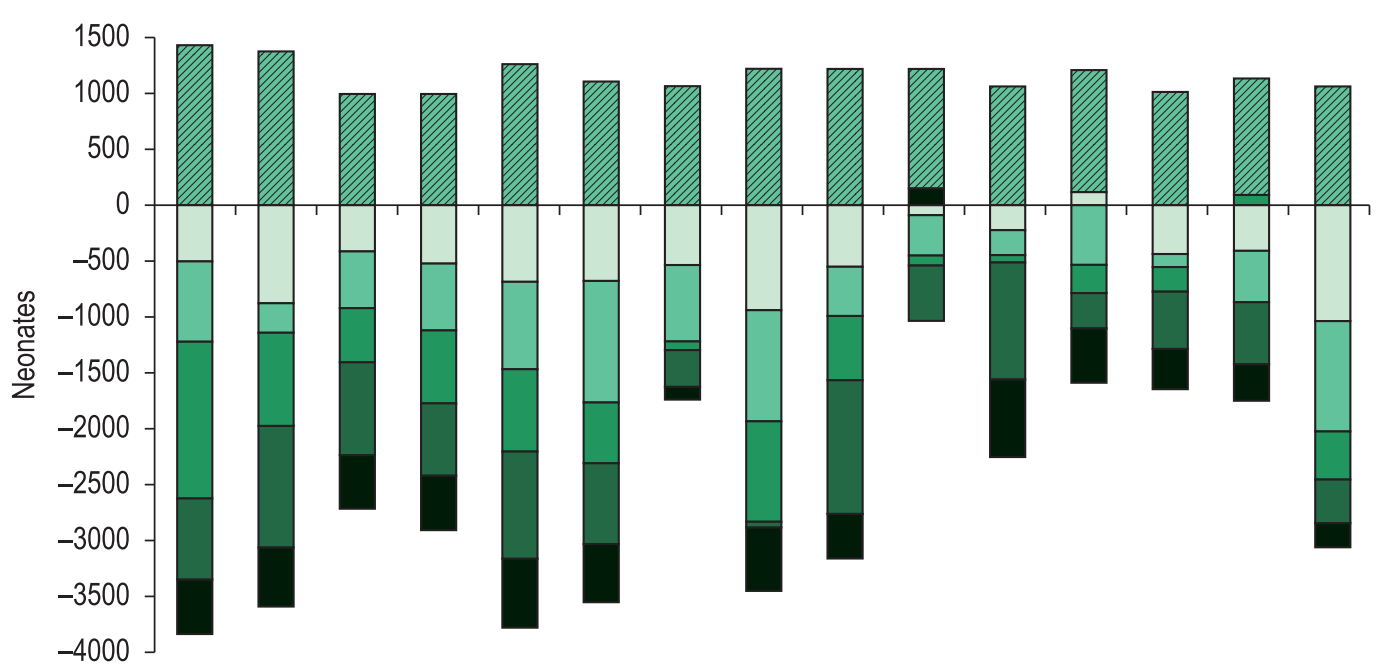

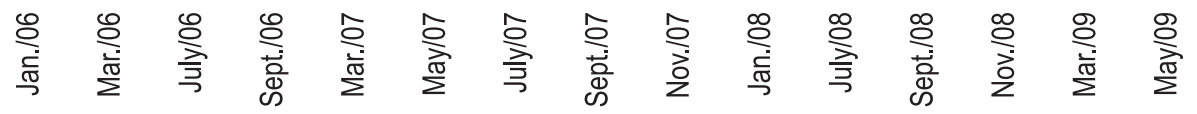

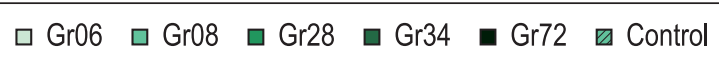

Figure 4. Difference in births between the control group and the samples.

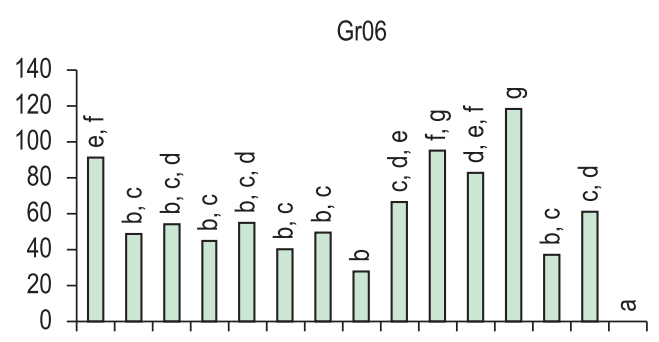

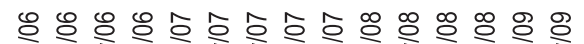

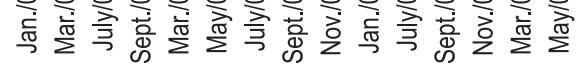

Gr28

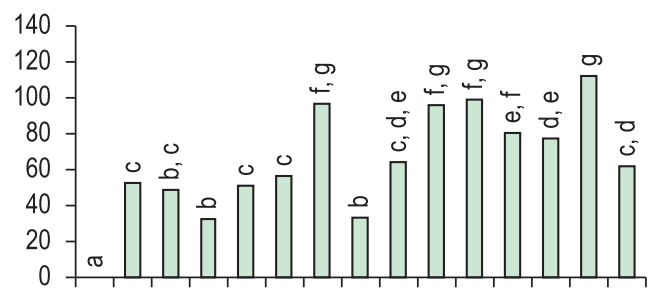

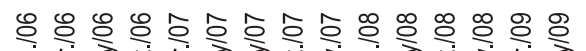

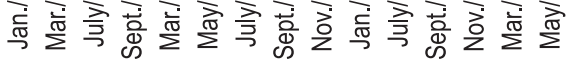

Gr72

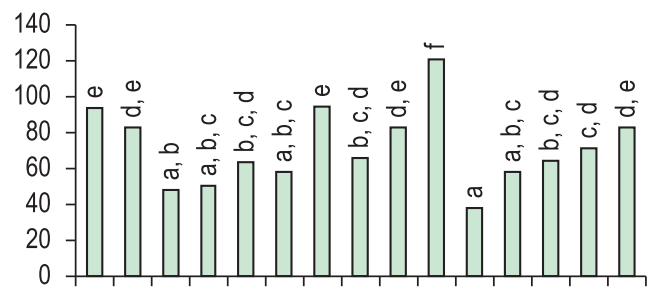

융ㅇㅇㅇㅇㅇㅇㅇㅇㅇㅇㅇㅇㅇㅇㅇㅇㅇㅇㅇㅇㅇ

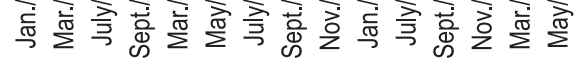

Figure 5. Comparison of births at each point during the period sampled, applying the Duncan Test. Months with the same letter were not significantly different according to the LSD test $(\mathrm{p} \leq 0.05)$.

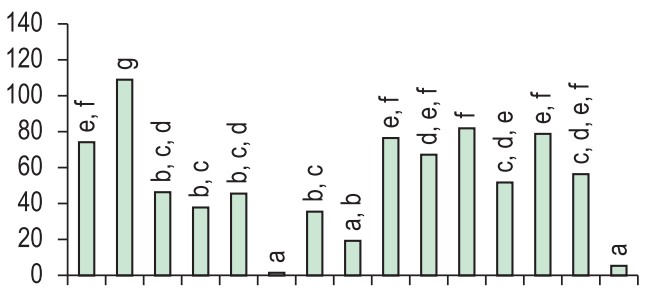

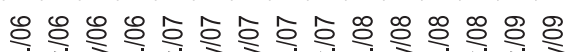

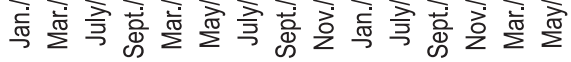

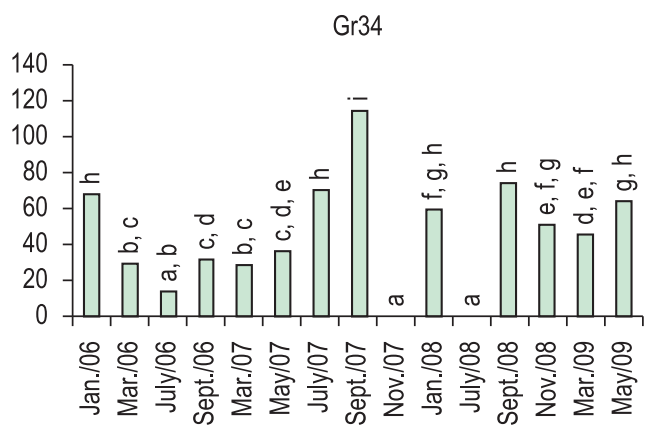


$(\mathrm{p} \leq 0.01)$ for reproduction. Only Gr28 showed a Spearman Correlation $(\mathrm{p} \leq 0.01)$ between survival and reproduction.

\section{Discussion}

Bioassays using cladocerans showed this river as an ecosystem that had been much changed in many areas. Physical and chemical parameters (OD, BOD, Turbidity, Total Solids, Nitrogen and Phosphate) evaluated between 1992 and 1994 indicate a trend towards a decrease in river quality from upstream to downstream (Leite et al., 1996). The action of xenobiotics in sediment was detected in a previous study that used Daphnia magna as a test organism (Terra et al., 2009). Depending on the sediment composition, the action of organisms may present different degrees of responses for the same total quantity of chemicals (DiToro et al., 1990). Byproducts of biological activity or chemical reactions in sediment can be remobilized to the liquid mass. According to Sundelin and Eriksson (2001) the contaminants accumulated in sediment may slowly return to the water. Aquatic animals can accumulate metals both directly from their aqueous environmental and from the prey they ingest, but metals accumulated through these two routes may have different physiological effects and geochemical fates (Twining and Fisher, 2004).

Species in direct contact with sediment such as these cladocerans (Ingersoll et al., 2000) are more severely affected than those that only inhabit the water column. Therefore the use of species such as D. magna that actively graze on sediment sample surfaces is more appropriate (Suedel et al., 1996). The presence of sediment particles in the gut of D. magna in assays using bulk sediment (Gillis et al., 2005), supports the importance and validity of using this genus in assays that evaluate the riverbeds, since, because they are non-selective filters, they ingest pollutants with the sediment.

The intake of xenobiotics contributed to toxicity, both at an acute and chronic level. Acute action was observed in Jan./06 (Gr28), Mar./06 (Gr06, Gr28, Gr34), July/06 (Gr34), May/07 (Gr06, Gr08, Gr72), Nov./07 (Gr34), Jan./08 (Gr08), July/08 (Gr34), Nov./08 (Gr06), Mar./09 (Gr06, Gr08), May/09 (Gr06, Gr08, Gr28).

Chronic action (88\%) was more constant than the acute one (23\%). Except for Mar./06 (Gr06, Gr08), Sept./07 (Gr34), Jan./08 (Gr06, Gr72), July/08 (Gr28) Sept./08 (Gr06), Mar./09 (Gr28), the other samplings induced reproductive activity below the expected level. It should be stressed that, although it is polluted, the physical and chemical quality standards in this river are usually in conformity with the legal standards. However, a chronic effect is found triggered by contaminants present in small doses. Thus, areas classified as pollution-free are responsible for slow changes in the biocenoses.

Comparing the sites, the Duncan Test showed a significant difference $(\mathrm{p} \leq 0.05)$ in the reproductive process, in 14 of the 15 samplings, except for Nov./08 when a mean precipitation $(84.5 \mathrm{~mm})$ below the historical mean (112 $\mathrm{mm}$ for that month) occurred. This may have reduced the current and caused xenobiotic sedimentation near the discharge point, preventing contaminant distribution. The smaller dispersion of contaminants may account for the absence of significance $(\mathrm{p} \leq 0.5)$ between the data that was found in that month. The same test identified a similarity in the mean of neonates between the subsequent Gr06, Gr08 and Gr28 (Mar./07, Sept./07, July/08), sites along the river. This similarity was also found between Gr06 and Gr08 (May/09), Gr28, Gr034 and Gr72 (May/09). During these months, the monthly mean precipitation was above the historical mean, which may have contributed to the distribution of pollutants among the nearby sites. The worse quality of Gr08 compared to Gr06 suggests two hypotheses: either Gr08 accumulated the xenobiotics brought from Gr28 while Gr06 was affected by reflux with dilution of the liquid mass, or in Gr08 there was a strong point contamination which was diluted by the time it reached Gr06. In order to define one of the two hypotheses it is necessary to perform a study with a route marker, since FEPAM (1996) reports reflux episodes in this river, provoking the influx of sewage from the North Zone of Porto Alegre in the area of Gr08. Xenobiotics carried into the river by sewage may be immediately absorbed by the microcrustaceans through ingestion or, after settling, due to the resuspension provoked by grazing. Thus, the substances ingested by the primary consumers may reach man through eating fish which are part of superior trophic levels in the food chain. Typology and frequency of the point sources are responsible for the variability of the results found in this study.

Variations in survival and reproduction related to season or rainfall regime were only observed on some occasions, indicating that these are not the aspects that determine environmental quality.

In this study, a Spearman Correlation ( $\mathrm{p} \leq 0.01)$ was observed between reproduction and survival 
for Gr06 and Gr08. Terra et al. (2009) observed a Spearman Correlation ( $\mathrm{p} \leq 0.05)$ between Jan./99 and Jun./03 among the same points only within the reproduction parameter. The repetition of results supports the hypothesis proposed in the study mentioned, where it takes the influence due to proximity between the points $(2 \mathrm{~km})$ into account.

A Spearman Correlation ( $\mathrm{p} \leq 0.05)$ between rainfall and survival, indicating the influence of rainfall on this biological parameter, was found at Gr06, Gr08 e Gr34. Between survival and reproduction it was only observed $(\mathrm{p} \leq 0.01)$ for $\mathrm{Gr} 28$, perhaps because it is located close to a stream with a high load of pollution, provoking high mortality besides inhibiting reproduction.

The Gravataí is a seasonal river due to its source in a swamp. For this reason more critical conditions are expected under extreme climatic conditions (flood or drought). The elevation of the water mass volume can increase the strength of the current that stirs up the bed, remobilizing substances deposited in surface layers, releasing xenobiotics carried from the soil, which contributes to contaminating the water body.

Gr34 presented low reproduction in $47 \%$ of the observations. On the other hand, at Gr72, upstream, the most abundant reproduction among all points occurred in $47 \%$ of the samplings. Comparing the births in the control group to Gr72, it was observed that in Jan./08 this site presented a higher reproduction level producing 1203 individuals. Gr72, located in the river headwaters, although often presenting lower results than expected, is less changed compared to the others. The best results at Gr72 occurred during the months when the mean monthly precipitation varied from 99 to $174 \mathrm{~mm}$ (values close to the historical mean). These data show that there has been less change in the source of Gravataí River so far, than in the middle and lower courses.

It is difficult for water to flow in Gravataí River because of the meanders. The river receives pollutants of various kinds and levels. The headwaters are in a swampy area; flow is $5.14 \mathrm{~m}^{3} / \mathrm{s}$ (IPH, 2002), and it runs more slowly than rivers in higher regions (Pineda and Schäfer, 1987). This characteristic distinguishes it from most rivers in the state. They slow down the flow and contribute to the low quality sometimes found in a few places in the headwaters, especially in areas where domestic effluents are discharged, as at Gr34 and Gr72.

A study (Savage et al., 2004) showed that domestic effluents are rich in $\mathrm{N}$ and can trigger an eutrophication process. Sundelin and Eriksson (2001) evaluating municipal effluent discharges, show that these are responsible for scarce DO in sediment. According to Routh et al. (2004) organic matter is an important component of sediment due to its association with biota, nutrient cycles, and geochemical processes. Ingested particles may trigger acute effects causing the death of the organism, or act silently producing a chronic effect. In the latter case only the reproductive changes are observed, as seen in many samples in this study. This often happens when the testorganisms respond to the xenobiotics that are part of the sediment, even if they are within the limits advocated by Brazilian legislation for physical and chemical parameters.

According to Twining and Fisher (2004) the metals with the strongest physiological effect are those ingested by zooplankton, and it is these that enter the food chain or are biologically recycled. Metal intake by microcrustaceans may be of concern to human beings when fish are used for food, since microcrustaceans are part of the trophic system of ichthyofauna. Croteau et al. (2005) say that the choice of food routes within the habitat may define the differences in exposure and metal accumulation in the organisms. Since long duration assays are done in this study, all the factors previously mentioned could interfere in the development of cladocerans. This is supported by the consistency between the data observed and the characteristics of the area studied.

In Jan./06 Gr28 presented 100\% deaths in 48 hours of exposure of the mothers. This result was expected, because at Gr28 there is a major contribution from sanitary sewage. Organic discharges, however, may at some times favor the reproduction of cladocerans, as in July/08 and Mar./09 at this site. D. magna needs $\mathrm{P}$ for survival, since these cladocerans reallocate $\mathrm{P}$ to the reproduction and molting processes (Becker and Boersma, 2005; He and Wang, 2008). The May/07 sample collected at site Gr08 provoked the death of $90 \%$ of the mothers during the first five days of exposure. The presence of sewage from different sources besides the accumulation of dumps in this area is responsible for the picture observed. The mortality found at Gr08 in May/07 may be the result of point sources, besides the xenobiotics discharged at $\mathrm{Gr} 06$ and brought there by the already mentioned current inversion.

The influx of waters in a river may mix layers constituting a major source of remobilization of 
dissolved and particulate material. Moreover, the extension of the mixture or the dissipation of influx is controlled mainly by the magnitude and density of influx (Chen et al., 2006).

Sensitive ecosystems like the Gravataí River are more easily damaged, especially when they receive discharges that induce eutrophication processes, such as the one that occurred at its source. Salomoni et al. (2007) observed a growing process of DO depletion and elevation of Turbidity, Conductivity, Chloride, and BOD. According to FEPAM (1996) the analyses of DO, BOD, Turbidity, Total Solids, Nitrogen and Phosphate performed between 1992 and 1994, indicated that the quality of this river had diminished from upstream to downstream. Although the Gravataí has areas that are quite strongly affected over its course, the worst responses found in this study are concentrated in the lower regions.

Comparing this study with previous ones (Terra et al., 2004, 2009) a fluctuation of the data and a decline in the environmental quality are observed. In 2004 the quality at Gr06 was worse than in 2005 (Terra et al., 2004), but the present study indicates 2007 as the worst of the three periods evaluated. This fluctuation may be the result of the location of this site, due to reflux action of the point sources or contaminants discharged upstream (FEPAM, 1996). Because of the currently obtained results, the present study reinforces previous conclusions (Terra et al., 2004; 2009; Salomoni et al., 2007) regarding river quality and the need to continue studying the area in order to supply data that will help make proposals for the recovery of the Gravataí River.

\section{Conclusion}

Transferring the information obtained in these bioassays to the natural environment, improper ecosystem quality conditions are found in Gravataí River, since both the survival and the reproduction of the test organisms were affected. More accurate answers require using a methodology in which there is long exposure of the samples, ensuring diagnoses that will provide technical support for safer conservation strategies.

\section{Acknowledgements}

This research was funded by FEPAM. The authors wish to thank the staff of the Sampling and FEPAGRO (Fundação Estadual de Pesquisa Agropecuária).

\section{References}

Associação Brasileira de Normas Técnicas - ABNT. 2004. NBR 12713. Ecotoxicologia aquática - Toxicidade aguda - Método de ensaio com Daphnia spp. (Cladocera, crustacea). Rio de Janeiro: ABNT.

Associação Brasileira de Normas Técnicas - ABNT. 2005. NBR 13373. Ecotoxicologia aquática - Toxicidade crônica - Métodos de ensaio com Ceriodaphnia spp (Crustacea, Cladocera. Rio de Janeiro: ABNT.

BALLANTINE, D., WALLING, DE. and LEEKS, GJL. 2009. Mobilization and transport of sediment - associated phosphorus by surface runoff. Water, Air, and Soil Pollution, vol. 196, p. 311-320. doi:10.1007/ s11270-008-9778-9

BECKER, C. and BOERSMA, M. 2005. Differential effects of phosphorus and fatty acids on Daphnia magna growth and reproduction. Limnology and Oceanography, vol. 50, no. 1, p. 388-397. doi:10.4319/lo.2005.50.1.0388

BRASIL. Conselho Nacional do Meio Ambiente CONAMA. Resolução no. 357, de 17 de Março de 2005. Dispóe sobre a classificação dos corpos de água e diretrizes ambientais para o seu enquadramento, bem como estabelece as condiçóes e padróes de lançamento de efluentes, e dá outras providências. Diário Oficial da União, Poder Executivo, Brasília, DF, 17 de abril de 2005. Available from: <http:// www.mma.gov.br>. Access in: 17 abr. 2005.

BURTON Jr., GA. 1992. Plankton, Macrophyte, Fish and Amphibian Toxicity Testing of Freshwater Sediments. In BURTON JUNIOR, GA. (Ed.). Sediment toxicity assessment. Boca Raton, Florida: Lewis Publishers. p. 167-182.

CHEN, YJ., WU, SC., LEE, BS. and HUNG, CC. 2006. Behavior of storm-induced suspension interflow in subtropical Feitsui Reservoir, Taiwan. Limnology and Oceanography, vol. 51, no. 2, p. 1125-1133. doi:10.4319/lo.2006.51.2.1125

CHU, SP. 1942. The influence of the mineral composition of the medium on the growth of planktonic algae. Part I. Methods and culture media. Journal of Ecology, vol. 30, p. 284-325. doi:10.2307/2256574

COWGILL, UM., HOPKINS, DL., APPLEGATH, SL., TAKAHASHI, IT., BROOKS, SD. and MILAZZO, DP. 1985. Brood size and neonate weight of Daphnia magna produced by nine diets. In BAHNER, RC. and HANSEN, DJ. (Eds.). Aquatic Toxicology and Hazard Assessment. Philadelphia: American Society for Testing and Materials. p. 233244.

CROTEAU, MN., LUOMA, SN. and STEWART, AR. 2005. Trophic transfer of metals along freshwater food webs: Evidence of Cadmium biomagnification in nature. Limnology and Oceanography, vol. 50, no. 5, p. 1511-1519. doi:10.4319/lo.2005.50.5.1511 
Departamento Nacional de Obras e Saneamento and Gesellschaft für Technische Zusammenarbeit DNOS/GTZ. 1985. Planejamento integrado dos recursos hidricos na bacia do rio Gravataí. Porto Alegre: DNOS.

DI TORO, DM., MAHONY, JD., HANSEN, DJ., JOHN SCOTT, K., HICKS, MB., MAYR, SM. and REDMOND, MS. 1990. Toxicity of cadmium in sediments: the role of acid volatile sulfite. Environmental Toxicology and Chemistry, vol. 9, p. 1487-1502. doi:10.1002/etc.5620091208

ELENDT, BP. and BIAS, WR. 1990. Trace nutrient deficiency in Daphnia magna cultured in standard medium for toxicity testing. Effects of the optimization of culture conditions on life history parameters of $D$. magna. Water Research, vol. 24, no. 9, p. 1157-1167. doi:10.1016/0043-1354(90)90180-E

EVENS, R., DE SCHAMPHELAERE, AC. and JANSSEN, CR. 2009. The effects of dietary nickel exposure on growth and reproduction of Daphnia magna. Aquatic Toxicology, vol. 94, n. 2, p. 138-144. doi:10.1016/j.aquatox.2009.06.011

Fundação Estadual de Proteção Ambiental Henrique Luiz Roessler - FEPAM, 1996. Qualidade das águas do rio Gravataí. período 1992 - 1994. Porto Alegre: FEPAM.

GERSICH, FM. and MAYES, MA. 1986. Acute toxicity tests with Daphnia magna Straus and Pimephales promelas Rafinesque in support of national pollutant discharge elimination permit requirements. Water Research, vol. 20, no. 7, p. 939941. doi:10.1016/0043-1354(86)90185-5

GILLIS, PL., CHOW-FRASER, P., RANVILLE, JF., ROSS, PE. and WOOD, CM. 2005. Daphnia need to be gut-cleared too: the effect of exposure to and ingestion of metal-contaminated sediment on the gut-clearance patterns of D. magna. Aquatic Toxicology, vol. 71, no. 2, p. 143-154. doi:10.1016/j. aquatox.2004.10.016

HAMILTON, MA., RUSSO, RC. and THURSTON, RV. 1977. Trimmed Spearman-Karber method for estimating median lethal concentrations in toxicity bioassays. Environmental Science and Technology, vol. 11 , no. 7, p. 714-719.

HE, X. and WANG, W-X. 2008. Stoichiometric regulation of carbon and phosphorus in P deficient Daphnia magna. Limnology and Oceanography, vol. 53, no. 1, p. 244-254. doi:10.4319/lo.2008.53.1.0244

INGERSOLL, CG., IVEY, CD., BRUNSON, EL., HARDESTY, DK. and KEMBLE, NE. 2000. Evaluation of toxicity: Whole-sediment versus overlying-water exposures with amphipod Hyalella azteca. Environmental Toxicology and Chemistry, vol. 19, no. 12, p. 2906-2910. doi:10.1002/ etc. 5620191209
Instituto de Pesquisas Hidráulicas - IPH. 2002. Identificação das alternativas possiveis e prováveis para a regularização das vazóes do rio Gravataí. Porto Alegre: IPH. cap. 7.

LEITE, EH., HAASE, JF., PINEDA, MDS., COBALCHINI, MS. and SILVA, MLC. 1996. Qualidade das águas do rio Gravatai. Porto Alegre: FEPAM. 65 p. Relatório Final.

NEBEKER, AV., CAIRNS, MA., GAKSTATTER, JH., MALUEG, KW., SCHUYTEMA, GS. and KRANCZYK, DF. 1984. Biological methods for determining toxicity of contaminated freshwater sediments to invertebrates. Environmental Toxicology and Chemistry, vol. 3, p. 617-630. doi:10.1002/ etc. 5620030412

PIETERS, BJ. and LIESS, M. 2006. Maternal nutritional state determines the sensitivity of Daphnia magna offspring to short-term Fenvalerate exposure. Aquatic Toxicology, vol. 76, p. 268-277. doi:10.1016/j. aquatox.2005.09.013

PINEDA, MDS. and SCHÄFER, A. 1987. Adequação de critérios e métodos de avaliação de águas superficiais baseada no estudo ecológico do rio Gravataí, Rio Grande do Sul, Brasil. Ciência e Cultura, vol. 39, no. 2, p. 198-206.

ROUTH, J., MEYER, PA., GUSTAFSSON, Ö., BASKARAN, M., HALLBEG, R. and SCHÖLDSTRÖM, A. 2004. sedimentary geochemical records of human-induced environmental changes in the Lake Brunnsviken watershed, Sweden. Limnology and Oceanography, vol. 49, no. 5, p. 15601569. doi:10.4319/lo.2004.49.5.1560

SALOMONI, SE., ROCHA, O. and LEITE, EH. 2007. Limnological Characterization of Gravataí River, Rio Grande do Sul State, Brazil. Acta Limnologica Brasiliensia, vol. 9, no. 1, p. 1-14.

SAVAGE, C., LEAVITT, PR. and ELMGREN, R. 2004. Distribution and retention of effluent nitrogen in surface sediments of a coastal bay. Limnology and Oceanography, vol. 49, no. 5, p. 1503-1511. doi:10.4319/lo.2004.49.5.1503

SUEDEL, BC., DEAVER, E. and ROGER Jr, JH. 1996. Experimental factors that may affect toxicity of aqueous and sediment-bound copper to freshwater organisms. Archives of Environmental Contamination and Toxicology, vol. 30, p. 40-46. doi:10.1007/ BF00211327

SUNDELIN, B. and ERIKSSON, A. 2001. Mobility and Bioavailability of trace metals in sulfidic coastal sediments. Environmental Science and Technology, vol. 20, no. 4, p. 748-756. doi:10.1002/etc.5620200408

TERRA, NR., FEIDEN, IR. and NUNES, EA. 2004. Efeito do sedimento do rio Gravataí na reprodução e na sobrevivência de Daphnia magna, 1820, Straus (Crustacea: Cladocera). In IV Simpósio Internacional de Qualidade Ambiental, 2004. Porto Alegre: ABES. 
TERRA, NR., FEIDEN, IR. and FACHEL, JMG. 2009. Monitoring of a swamp river contaminated by multiple waste. Acta Limnologica Brasiliensia, vol. 21, no. 1, p. 79-88.

TWINING, BS. and FISCHER, NS. 2004. trophic transfer of trace metals from protozoa to mesozooplankton. Limnology and Oceanography, vol. 49, no. 1, p. 28-39

YU, RQ. and WANG, WX. 2002. Trace metal assimilation and release budget in Daphnia magna. Limnology and Oceanography, vol. 47, no. 2, p. 495-504.

Received: 12 May 2010 Accepted: 10 April 2011 